\title{
Marta Dacosta*
}

\section{"Ordenemos o universo" e outros poemas}

\author{
ORDENEMOS o universo \\ arrombemos constelacións e órbitas \\ saquemos brillo á Polar \\ e a todas as que nos guían. \\ Descolguemos as nubes, \\ lavar, dobrar, gardar, \\ as súas extensións inútiles, \\ incómodas para a viaxe. \\ Eu son Penélope \\ e rexeito teas e fíos \\ non te vou agardar. \\ Ordenemos o universo \\ lavemos a cuberta e botemos pola borda \\ tanto lastre inútil, \\ e así, sen peso, \\ co universo ordenado \\ debuxemos un mapa para a viaxe.
}


ORDENEMOS o universo arrumemos constelações e órbitas puxemos o lustro à estrela polar e a todas as estrelas que nos guiam

Vamos descolar as nuvens, lavar, dobrar, salvar as suas extensões inúteis, incómodas para a viagem. Eu sou Penélope e rejeito teias e fios. Não vou esperar por ti.

Ordenemos o universo vamos lavar o convés e lançar ao mar tanto lastro inútil, e assim, sem peso, com o universo ordenado desenhemos um mapa para a viagem.

As amantes de Hamlet, 2003 Trad. Ana Luísa Amaral 


\author{
TIRA a roupa \\ mostra o corpo \\ as cicatrices delatoras \\ ergue o brazo, deixa \\ que a axila mostre \\ que te roeu o veleno \\ até desfigurarte \\ non ocultes o ventre \\ a liña que o cruza e que nos conta \\ que o parto foi difícil \\ mostra o corpo \\ tira a roupa \\ e deixa que as cicatrices \\ nos conten esa historia \\ a túa historia \\ que deixen claro \\ que venciches
}

Na casa da avoa, 2017 
REDE INTERNACIONAL LYRACOMPOETICS

TIRA a roupa toda

mostra o corpo

as cicatrizes reveladoras

levanta o braço, possa a axila expor

como te roeu o veneno

até te desfigurar

não escondas o ventre,

a linha que o cruza e nos conta

que o parto foi difícil

mostra o corpo

tira a roupa

e deixa que as cicatrizes

nos contem essa história

a tua história

que deixem claro

que venceste.

Na casa da avoa, 2017

Trad. Ana Luísa Amaral 

monstro fabricado polo home...

\section{EXHÍBENTE}

mercadoría desprezábel

para o seu refinado gusto

branco

europeo

superior

imperialista

exhíbente

obsesionados

polo teu sexo

polo teu corpo

non poden apartar

os seus ollos

de ti, as súas conversas

de ti, as súas mans

de ti

exhíbente

para insultarte

para sentirse superiores

dominarte

posuírte

extinguirte

medorentos ante

a muller

que exhibe a súa dignidade

máis alá da túa morte

exhíbente

como símbolo de posesión

demostración da grandeza

dos invasores

do imperialismo 
REDE INTERNACIONAL LYRACOMPOETICS

Marta Dacosta

do poder alicerzado na dominación

no roubo

no exterminio

\section{colonialismo}

mais a voz das mulleres do teu pobo

cunha firmeza inquebrantábel, reclámate

e fai abalar as leis do imperio

aferrado aos trofeos da impudicia

dignidade

ser parte da voz

que te reclama

Na casa da avoa, 2017 


\title{
EXIBEM-TE
}

\author{
És exibida \\ mercadoria desprezível \\ para o gosto deles refinado \\ branco \\ europeu \\ superior \\ imperialista \\ exibem o teu corpo \\ obcecados \\ pelo teu sexo \\ pelo teu corpo \\ não conseguem afastar \\ os olhos de ti, as conversas \\ de ti, as mãos \\ de ti \\ exibem o teu corpo \\ para te insultarem \\ para se sentirem superiores \\ te dominarem \\ possuírem \\ te eliminarem \\ amedrontados perante \\ a mulher \\ que exibe a sua dignidade \\ mais além da morte \\ exibem o teu corpo \\ como símbolo de posse \\ demostração da grandeza \\ dos invasores \\ do imperialismo
}


REDE INTERNACIONAL LYRACOMPOETICS

Marta Dacosta

do poder alicerçado na dominação

no roubo

no extermínio

colonialismo

mas a voz das mulheres do teu povo

essa voz de firmeza inquebrantável, reclama-te

e faz abalar as leis do império

ancorado aos troféus da insolência

dignidade

é ser parte da voz

que te reclama

Na casa da avoa, 2017

Trad. Ana Luísa Amaral 


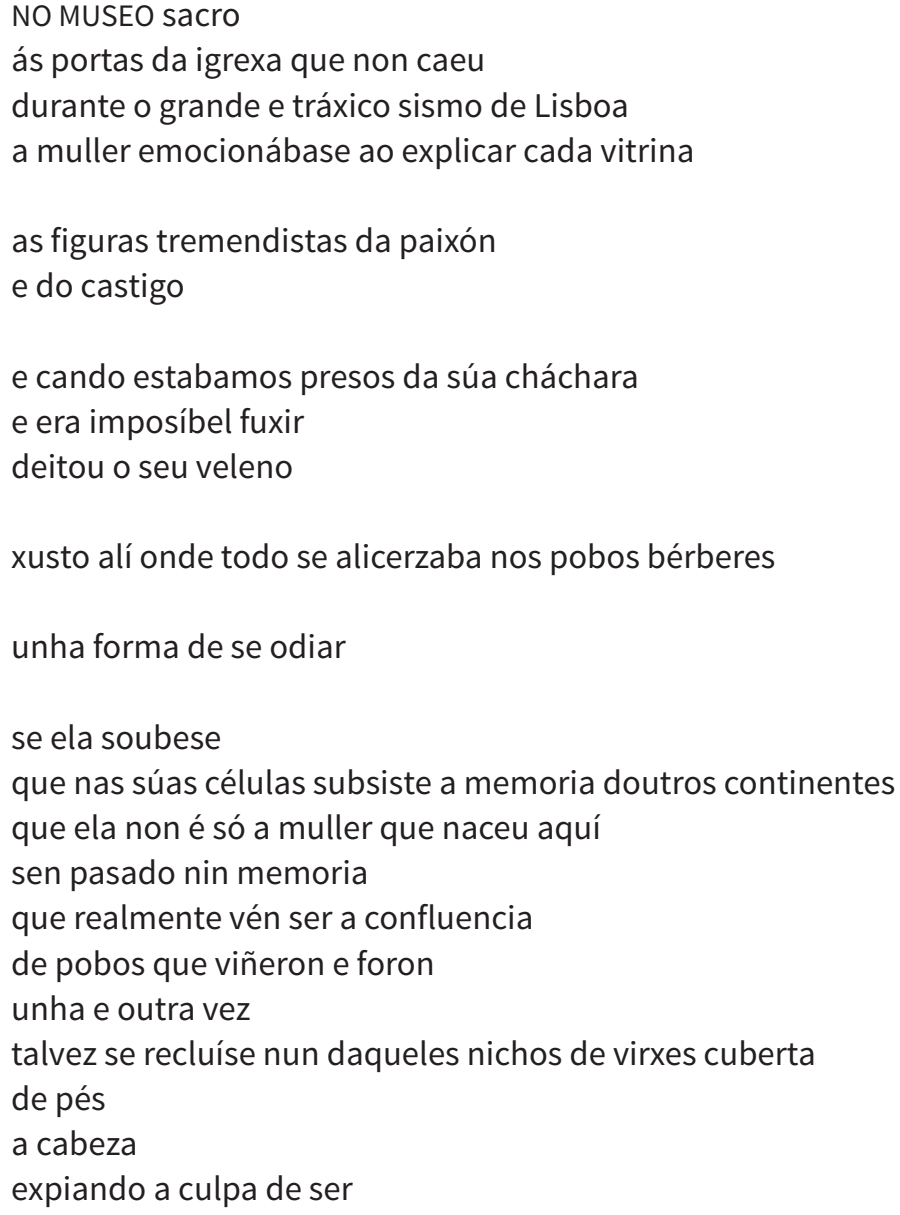

inedito, 2019 


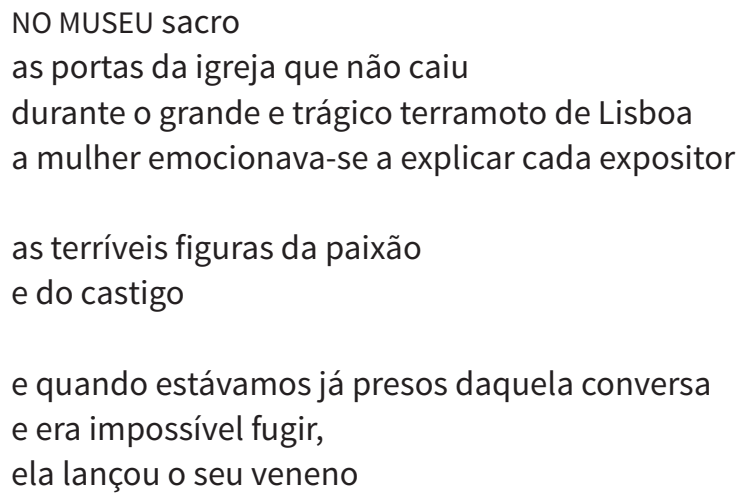


NOTA

* Marta Dacosta Alonso (Vigo, 1966) é autora de Crear o mar en Compostela (1994 e 2004), Pel de ameixa (1996), Setembro (1998), En atalaia alerta (2000), As Amantes de Hamlet (2003), Cinza (2009), Acuática alma (2011), Argola (2013), Dun lago escuro (2014), Na casa da avoa (2017) e Labirinto ou memoria (2018). Foi distinguida, entre outros, com os seguintes prémios: González Garcés 1995, Martín Códax 1998, O Figurante 2013 e Joam Carballeira 2013. A sua obra figura em diferentes antologias e está traduzida para espanhol, catalão, russo e inglês. Tem colaborado com diferentes meios de comunicação e atualmente mantém é autora da coluna "Filla de Medea" em Nòs Diario. 